\title{
ANALISIS FINANCIAL DISTRESS DENGAN MENGGUNAKAN METODE Z-SCORE (ALTMAN), SPRINGATE, DAN ZMIJEWSKI UNTUK MEMPREDIKSI KEBANGKRUTAN PERUSAHAAN ROKOK YANG TERDAFTAR DI BEI PADA TAHUN 2013-2016
}

\author{
Eurike Fitria Prasandri \\ Fakultas Ekonomi, Universitas Islam Lamongan
}

\begin{abstract}
ABSTRAK
Penelitian ini bertujuan untuk mengetahui perbandingan antara metode Altman Z-Score, metode Springate dan metode Zmijewski dalam memprediksi kebangkrutan perusahaan rokok yang terdaftar di Bursa Efek Indonesia (BEI) tahun 2013-2016. Data yang digunakan berupa laporan keuangan yang telah diterbitkan oleh perusahaan di website Indonesian Stock Exchange. Sampel yang digunakan adalah perusahaan rokok yang terdaftar di Bursa Efek Indonesia selama tahun 2013-2016. Teknik pengambilan sampel adalah purposive sampling dengan total sampel yang didapat sebanyak 4 perusahaan. Hasil dari penelitian menunjukkan bahwa metode Zmijewski memiliki tingkat presentase kebangkrutan paling rendah dibandingkan dengan kedua metode lainnya yaitu sebesar 18,75 persen. Kedua metode tersebut memiliki tingkat presentase kebangkrutan yang sama yaitu sebesar 25,00 persen. Maka dari itu metode prediksi yang cocok untuk perusahaan rokok di Indonesia adalah metode Zmijewski guna menarik investor yang akan menanamkan sahamya.
\end{abstract}

Kata kunci : Altman Z-Score, Kebangkrutan, Kesulitan Keuangan, Springate, dan Zmijewski.

\section{PENDAHULUAN}

Seiring dengan perkembangan perubahan ekonomi, telah bermunculan di Indonesia berbagai macam produk rokok dimana banyak perusahaan bersaing ketat untuk kinerja yang optimal. Pengelolaan keuangan merupakan hal penting untuk kemajuan dan perkembangan suatu perusahaan. Oleh karena itu, setiap perusahaan memerlukan suatu strategi dan perencanaan yang baik dalam menjalankan usahanya agar dapat tetap bertahan dan berkembang.

$$
\text { Kebangkrutan merupakan }
$$
masalah esensial yang harus diwaspadai oleh perusahaan. Karena jika perusahaan sudah terkena kesulitan keuangan (financial distress), maka perusahaan tersebut benar-benar mengalami kegagalan usaha atau kebangkrutan. Oleh sebab itu perusahaan harus sedini mungkin melakukan berbagai analisis terutama 
analisis yang menyangkut kebangkrutan suatu perusahaan. Dengan melakukan analisis maka sangat bermanfaat bagi perusahaan untuk melakukan antisipasi atau meningkatkan kewaspadaan yang dapat mengurangi maupun menghindari resiko kebangkrutan tersebut.

Analisis kebangkrutan dilakukan untuk memperoleh peringatan awal kebangkrutan tersebut. Semakin awal ditemukannya indikasi kebangkrutan tersebut, semakin baik bagi pihak manajemen karena pihak manajemen bisa melakukan perbaikan-perbaikan. Berbagai analisis dikembangkan untuk memprediksi potensi awal kebangkrutan perusahaan. Analisis yang banyak digunakan saat ini adalah analisis diskriminan Altman, dimana analisis ini mengacu pada rasio-rasio keuangan perusahaan.

Berdasarkan latar belakang yang diuraikan diatas, maka dapat dirumuskan masalah sebagai berikut: “ Bagaimana perbandingan hasil prediksi kebangkrutan yang dihasilkan dari metode Altman Z-Score, Springate dan Zmijewski.

Berdasarkan latar belakang diatas, prediksi kebangkrutan diperlukan sebagai early warning sebelum pengambilan keputusan investasi di suatu perusahaan, sehingga tujuan penelitian ini adalah mengetahui perbandingan hasil prediksi kebangkrutan yang dihasilkan dari metode Altman Z-Score, Springate dan Zmijewski.

\section{METODE PENELITIAN}

\subsection{Jenis Penelitian}

Berdasarkan tujuan penelitian, Penelitian ini merupakan penelitian deskriptif, yaitu penelitian yang dilakukan untuk mengetahui dan mampu untuk menjelaskan karakteristik variabel yang diteliti dalam suatu situasi. Penelitian ini dilakukan untuk memberikan gambaran yang lebih detail mengenai suatu gejala atau fenomena.

\subsection{Teknik Penarikan Sampel}

Metode pengambilan sampel yang digunakan adalah purposive sampling. Pengambilan sampel secara purposive didasarkan pada suatu pertimbangan tertentu yang dibuat oleh peneliti sendiri, berdasarkan ciri atau sifat-sifat populasi yang sudah diketahui sebelumnya. Populasi dalam penelitian ini adalah perusahaan rokok yang terdaftar di Bursa Efek Indonesia. Sampel dalam penelitian ini adalah 
perusahaan rokok dengan kriteria sebagai berikut:

1. Merupakan perusahaan rokok yang terdaftar di Bursa Efek Indonesia.

2. Mempunyai laporan keuangan yang lengkap dan telah menerbitkan laporan keuangan tiga tahun secara berturut-turut dalam periode pangamatan.

Berdasarkan kriteria-kriteria yang telah ditetapkan dalam pengambilan sampel, maka perusahaan rokok yang terdaftar di BEI pada periode 20132016 sebanyak 4 (empat) perusahaan. Berikut ini daftar nama perusahaan rokok yang dijadikan sampel pada penelitian ini dapat dilihat pada Tabel 1 .

Tabel 1. Daftar Nama Perusahaan Rokok

\begin{tabular}{|c|l|c|}
\hline No. & \multicolumn{1}{|c|}{$\begin{array}{c}\text { Nama } \\
\text { Perusahaan }\end{array}$} & $\begin{array}{c}\text { Kode } \\
\text { Saham }\end{array}$ \\
\hline 1. & $\begin{array}{l}\text { PT Gudang Garam } \\
\text { Tbk. }\end{array}$ & GGRM \\
\hline 2. & $\begin{array}{l}\text { PT HM Sampoerna } \\
\text { Tbk. }\end{array}$ & HMSP \\
\hline 3. & $\begin{array}{l}\text { PT Bentoel } \\
\text { Internasional } \\
\text { Investama Tbk. }\end{array}$ & RMBA \\
\hline 4. & $\begin{array}{l}\text { PT Wismilak Inti } \\
\text { Makmur Tbk. }\end{array}$ & WIIM \\
\hline
\end{tabular}

Sumber: data diolah

\subsection{Metode Penngumpulan Data}

Jenis data yang digunakan dalam penelitian ini merupakan data sekunder, yaitu laporan keuangan yang diterbitkan perusahaan-perusahaan rokok yang terdaftar di Bursa Efek Indonesia periode 2012 sampai 2016. Data sekunder dalam laporan keuangan yang diambil berupa laporan tahunan meliputi laporan rugi laba, neraca, dan laporan arus kas yang dipublikasikan mulai tahun 2012-2016.

Penelitian ini menggunakan data historis perusahaan berupa laporan keuangan dan catatan-catatan yang berkaitan dengan penelitian ini. Data laporan keuangan perusahaanperusahaan rokok yang terdaftar dalam Bursa Efek Indonesia dapat diambil melalui website resmi BEI yaitu www.idx.co.id. Metode pengumpulan data dilakukan secara dokumentasi, yaitu mengumpulkan data laporan keuangan perusahaan-perusahaan yang diteliti.

\subsection{Metode Analisis Data}

Metode analisa data pada laporan keuangan digunakan untuk mengukur, mengetahui, dan menggambarkan kemungkinan terjadinya financial Distress pada Perusahaan Rokok Di Indonesia yaitu PT Gudang Garam Tbk, PT HM Sampoerna Tbk, PT Bentoel Internasional Investama Tbk, dan PT Wismilak Inti Makmur Tbk Periode 2013-2016. Keseluruhan data Laporan 
keuangan pada PT Gudang Garam Tbk, PT HM Sampoerna Tbk, PT Bentoel Internasional Investama Tbk, dan PT Wismilak Inti Makmur Tbk Periode 2013-2016 yang terkumpul selanjutnya dianalisis untuk dapat memberikan jawaban dari masalah yang dibahas dalam penelitian ini.

\subsection{Metode Altman Z-Score}

Pada tahun 1983, 1984 model prediksi kebangkrutan dikembangkan lagi oleh Altman untuk beberapa negara, dari penelitian tersebut ditemukan nilai $\mathrm{Z}$, yang dicari dengan persamaan diskriminan sebagai berikut : Hanafi \& Halim (2003:275) dalam Kamal (2012).

$Z_{i}=1,2 X_{1}+1,4 X_{2}+3,3 X_{3}+0,6 X_{4}+$ $1,0 \mathrm{X}_{5}$

Dimana:

$\mathrm{X}_{1}=$ Working Capital to Total Assets (Modal Kerja/Total Aset)

$\mathrm{X}_{2}=$ Retained Earning to Total Assets (Laba Ditahan/Total Aset)

$\mathrm{X}_{3}=$ Earning Before Interest and Taxes (EBIT) to Total Assets (Pendapatan Sebelum Dikurangi Biaya Bunga/Total Aset)

$$
\begin{aligned}
\mathrm{X}_{4} & =\text { Market Value of Equity to } \\
& \text { Book Value of Total Liabilities } \\
& \text { (Nilai Pasar Ekuitas/Nilai Total } \\
& \text { Utang) } \\
\mathrm{X}_{5} \quad & \text { Sales to Total Assets } \\
& \text { (Penjualan/Total Aset) }
\end{aligned}
$$

Tabel 2. Kriteria Z-Score Altman

\begin{tabular}{|l|c|}
\hline Area Z-Score & Score Altman \\
\hline Safe Zone & Z-Score $>2,99$ \\
\hline Grey Zone & $1,81<$ Z-Score $<2,99$ \\
\hline Distress Zone & Z-Score $<1,81$ \\
\hline
\end{tabular}

\subsection{Metode Springate}

Menurut Peter dan Yoseph (2011), model ini dikembangkan pada tahun 1978 oleh Gorgon L.V. Springate. Dengan mengikuti prosedur yang dikembangkan Altman, Springate menggunakan step-wise multiple discriminate analysis untuk memilih empat dari 19 rasio keuangan yang popular sehingga dapat membedakan perusahaan yang berada dalam zona bangkrut atau zona aman.

Menggunakan model Springate (1978) yang dikembangkan oleh Rajasekar, et al (2014) mendiskripsikan dengan rumus sebagai berikut: $\mathrm{S}=1,03 \mathrm{~A}+3,07 \mathrm{~B}+0,66 \mathrm{C}+0,4 \mathrm{D}$ Dimana:

S = Indeks Keseluruhan 

A $=$ Modal Kerja Terhadap Total Aktiva
B = Laba Sebelum Bunga dan
Pajak Terhadap Total Aktiva
C = Laba Sebelum Pajak Terhadap Total Kewajiban Lancar
$\mathrm{D} \quad=$ Penjualan Terhadap Total Aktiva

Tabel 3. Kriteria Score Springate

\begin{tabular}{|l|c|}
\hline \multicolumn{1}{|c|}{ Area Springate } & Score \\
\hline Safe Zone & $\mathrm{S}>0,862$ \\
\hline Distress Zone & $\mathrm{S}<0,862$ \\
\hline
\end{tabular}

\subsection{Metode Zmijewski}

Menurut Nurcahyanti (2015), menurut Zmijewski ini mengkritik metode pengambilan sampel yang digunakan pendahulunya. Menurutnya, teknik matched-pair sampling cenderung memunculkan teknik random sampling dalam penelitiannya mensyaratkan satu hal yang krusial. Proporsi dari sampel dan populasi harus ditentukan di awal, sehingga didapat besaran frekuensi kebangkrutan. Frekuensi kebangkrutan dapat diperoleh dengan membagi jumlah sampel yang mengalami kebangkrutan dengan jumlah sampel keseluruhan. Sampel yang digunakan berjumlah 840 perusahaan, terdiri dari 40 perusahaan yang mengalami kebangkrutan dan 800 yang tidak mengalami kebangkrutan. Metode statistik yang digunakan sama dengan yang digunakan Ohlson, yaitu regresi logit. Dengan menggunakan metode tersebut, menghasilkan metode sebagai berikut:

$X=-4,3-4,5 X_{1}+5,7 X_{2}+0,004 X_{3}$

Dimana:

$\mathrm{X}=$ Indeks Keseluruhan

$\mathrm{X}_{1}=$ Laba Bersih Terhadap Total Aktiva

$\mathrm{X}_{2}=$ Total Kewajiban Terhadap Total Aktiva

$\mathrm{X}_{3}=$ Aktiva Lancar Terhadap Kewajiban Lancar

Tabel 4. Kriteria Score Zmijewski

\begin{tabular}{|l|c|}
\hline Area Zmijewski & Score \\
\hline Safe Zone & $\mathrm{X}<0$ (negatif) \\
\hline Distress Zone & $\mathrm{X}>0$ (positif) \\
\hline
\end{tabular}

\section{HASIL PENELITIAN DAN PEMBAHASAN}

Tujuan dari perhitungan ini adalah untuk memprediksi kebangkrutan yang diperlukan sebagai early warning sebelum pengambilan keputusan investasi di suatu perusahaan. Berikut ini adalah hasil prediksi kebangkrutan dengan menggunakan ketiga metode 
yaitu Altman Z-Score, Springate dan Zmijewski pada periode 2013-2016.

\subsection{Metode Altman Z-Score}

Berdasarkan penelitian pada 4 perusahaan rokok periode 2013-2016 dengan metode Altman menggunakan persamaan $Z_{i}=1,2 X_{1}+1,4 X_{2}+3,3 X_{3}$ $+0,6 X_{4}+1,0 X_{5}$. Setelah dilakukan perhitungan setiap variabel dengan cutoff $\mathrm{Z}>2,99$ termasuk kategori safe zone, $1,81<\mathrm{Z}<2,99$ termasuk kategori grey zone, dan $\mathrm{Z}<1,81$ merupakan kategori distress zone. Maka diperoleh hasil $\mathrm{Z}$ dengan kategori sebagai berikut:

Tabel 5. Hasil Nilai $X_{1}-X_{5}$ Tahun 2013-2016

\begin{tabular}{|c|c|c|c|c|c|c|c|}
\hline \multirow[b]{2}{*}{$\begin{array}{l}\mathbf{N} \\
\mathbf{0}\end{array}$} & \multirow[b]{2}{*}{$\begin{array}{c}\text { Perusa } \\
\text { haan } \\
\text { Rokok } \\
\text { di } \\
\text { Bursa } \\
\text { Efek } \\
\text { Indones } \\
\text { ia }\end{array}$} & \multirow[b]{2}{*}{$\begin{array}{l}\text { T } \\
\mathbf{a} \\
\mathrm{h} \\
\mathbf{u} \\
\mathrm{n} \\
\mathbf{2} \\
0 \\
1 \\
3 \\
- \\
2 \\
0 \\
1 \\
6\end{array}$} & \multicolumn{5}{|c|}{ Hasil Z-Score } \\
\hline & & & $\left(\mathbf{X}_{1}\right)$ & $\left(\mathbf{X}_{2}\right)$ & $\left(\mathbf{X}_{3}\right)$ & $\left(\mathbf{X}_{4}\right)$ & $\left(\mathbf{X}_{5}\right)$ \\
\hline \multirow[t]{4}{*}{1} & \multirow[t]{4}{*}{$\begin{array}{l}\text { PT } \\
\text { Gudang } \\
\text { Garam } \\
\text { Tbk. }\end{array}$} & $\begin{array}{l}2 \\
0 \\
1 \\
3 \\
\end{array}$ & 0,343 & 0,006 & 0,435 & 32,7 & 1,092 \\
\hline & & $\begin{array}{l}2 \\
0 \\
1 \\
4 \\
\end{array}$ & 0,304 & 0,005 & 0,486 & 33,3 & 1,12 \\
\hline & & $\begin{array}{l}2 \\
0 \\
1 \\
5\end{array}$ & 0,350 & 0,004 & 0,523 & 32,4 & 1,108 \\
\hline & & $\begin{array}{l}2 \\
0 \\
1 \\
6\end{array}$ & 0,387 & 0,004 & 0,531 & 13,9 & 1,212 \\
\hline \multirow[t]{2}{*}{2} & \multirow[t]{2}{*}{$\begin{array}{l}\text { PT HM } \\
\text { Sampoe } \\
\text { rna Tbk. }\end{array}$} & $\begin{array}{l}2 \\
0 \\
1 \\
3\end{array}$ & 0,400 & 0,005 & 2,417 & 0,456 & 2,738 \\
\hline & & $\begin{array}{l}2 \\
0 \\
1 \\
4\end{array}$ & 0,303 & 0,004 & 2,384 & 0,269 & 2,843 \\
\hline
\end{tabular}

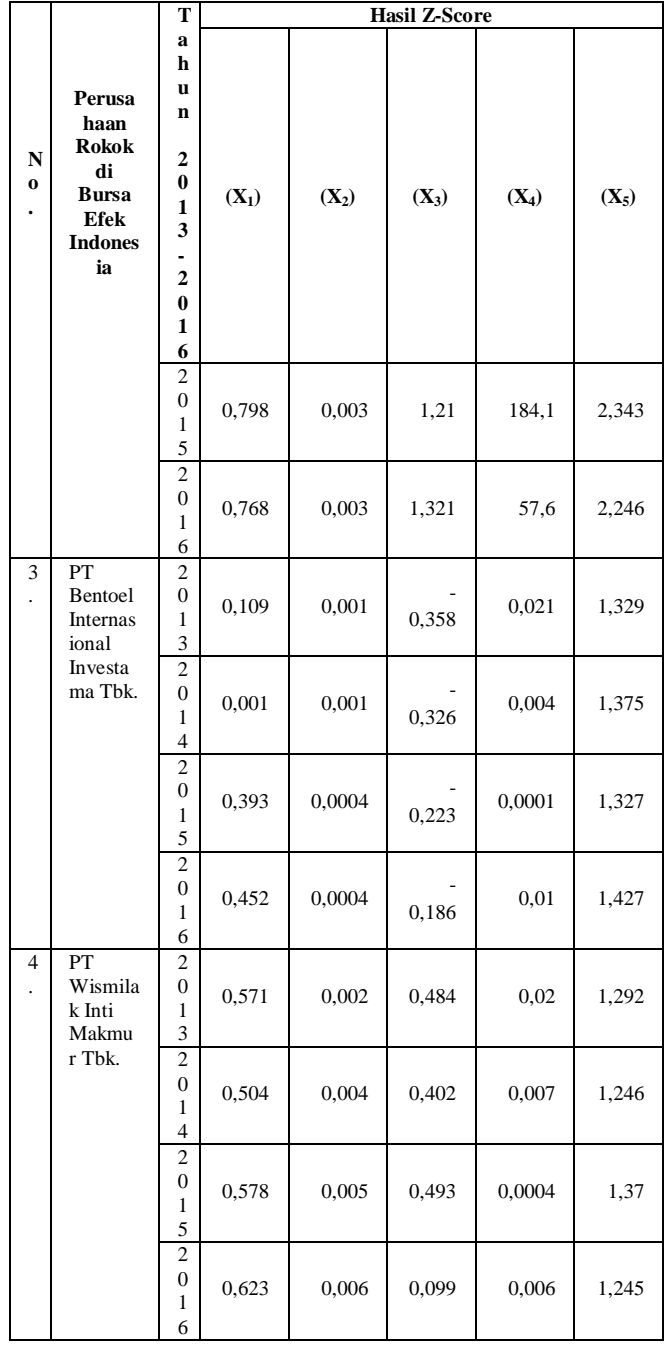

Sumber: data diolah

Tabel 6. Hasil Nilai Z-Score Tahun 2013-2016

\begin{tabular}{|c|c|c|c|c|}
\hline No. & $\begin{array}{c}\text { Perusahaan } \\
\text { Rokok di } \\
\text { Bursa Efek } \\
\text { Indonesia }\end{array}$ & $\begin{array}{l}\text { Tahun } \\
\text { 2013- } \\
2016\end{array}$ & $\begin{array}{c}\text { Total } \\
\text { Hasil Z- } \\
\text { Score }\end{array}$ & $\begin{array}{l}\text { Kate } \\
\text { gori }\end{array}$ \\
\hline \multirow[t]{4}{*}{1.} & \multirow{4}{*}{$\begin{array}{l}\text { PT Gudang } \\
\text { Garam Tbk. }\end{array}$} & 2013 & 34,576 & $S$ \\
\hline & & 2014 & 35,215 & $S$ \\
\hline & & 2015 & 34,385 & $S$ \\
\hline & & 2016 & 16,034 & $S$ \\
\hline \multirow[t]{4}{*}{2.} & \multirow{4}{*}{$\begin{array}{l}\text { PT HM } \\
\text { Sampoerna } \\
\text { Tbk. }\end{array}$} & 2013 & 6,016 & $S$ \\
\hline & & 2014 & 5,803 & $S$ \\
\hline & & 2015 & 188,454 & $S$ \\
\hline & & 2016 & 61,938 & $S$ \\
\hline \multirow[t]{4}{*}{3.} & \multirow{4}{*}{$\begin{array}{l}\text { PT Bentoel } \\
\text { Internasional } \\
\text { Investama } \\
\text { Tbk. }\end{array}$} & 2013 & 1,102 & $D$ \\
\hline & & 2014 & 1,055 & $D$ \\
\hline & & 2015 & 1,498 & $D$ \\
\hline & & 2016 & 1,703 & $D$ \\
\hline \multirow[t]{4}{*}{4.} & \multirow{4}{*}{$\begin{array}{l}\text { PT } \\
\text { Wismilak } \\
\text { Inti Makmur } \\
\text { Tbk. }\end{array}$} & 2013 & 2,369 & $G$ \\
\hline & & 2014 & 2,163 & $G$ \\
\hline & & 2015 & 2,446 & $G$ \\
\hline & & 2016 & 1,988 & $G$ \\
\hline
\end{tabular}

Sumber: data diolah 
Keterangan:

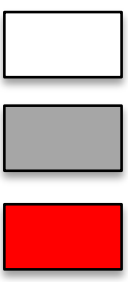

\section{$=$ Safe Zone (Zona Aman) \\ = Grey Zone (Zona / Area Abu-abu) \\ = Distress Zone (Zona Kesulitan)}

Disimpulkan dari keempat perusahaan Rokok di Indonesia, sesuai hasil yang telah didapatkan, yaitu yang dominan berada dalam zona abu-abu yaitu perusahaan PT Wismilak Inti Makmur Tbk.. Perusahaan dari tahun ke tahun menunjukkan bahwa mempunyai hutang yang cukup besar, namun perusahaan masih mampu untuk membayar hutang-hutang tersebut meskipun perusahaan hanya memperoleh laba bersih yang relatif kecil. Dalam zona ini perusahaan bisa saja mengalami kesulitan keuangan atau kebangkrutan, maka dari itu perusahaan harus lebih giat lagi dalam meningkatkan produktivitasnya atau bisa juga mengganti strategi yang sudah ada dengan strategi yang lebih baik lagi. Selanjutnya yang dominan berada dalam zona kesulitan keuangan yaitu perusahaan PT Bentoel Internasional Investama Tbk., perusahaan ini mengalami kesulitan keuangan. Perusahaan selama 4 (empat) tahun menunjukkan laba sebelum bunga dan pajak bernilai negatif, atau dapat dikatakan perusahaan dari tahun ke tahun selalu mengalami kerugian. Jika perusahaan mengalami hal ini terus berkelanjutan maka perusahaan akan mengalami kebangkrutan.

\subsection{Metode Springate}

Berdasarkan penelitian pada 4 perusahaan rokok periode 2013-2016 dengan metode Altman menggunakan persamaan $\mathrm{S}=1,03 \mathrm{~A}+3,07 \mathrm{~B}+0,66 \mathrm{C}$ $+0,4 \mathrm{D}$. Setelah dilakukan perhitungan setiap variabel dengan cut-off $\mathrm{S}>0,862$ termasuk kategori safe zone, dan $\mathrm{S}<$ 0,862 merupakan kategori distress zone. Maka diperoleh hasil S dengan kategori sebagai berikut:

Tabel 7. Hasil Nilai A-D Tahun 20132016

\begin{tabular}{|c|c|c|c|c|c|c|}
\hline \multirow[b]{2}{*}{ No } & \multirow[b]{2}{*}{$\begin{array}{c}\text { Perusa } \\
\text { haan } \\
\text { Rokok } \\
\text { di } \\
\text { Bursa } \\
\text { Efek } \\
\text { Indone } \\
\text { sia }\end{array}$} & $\mathbf{T}$ & \multicolumn{4}{|c|}{ Springate } \\
\hline & & $\begin{array}{l}\text { u } \\
\text { n } \\
2 \\
0 \\
1 \\
3 \\
- \\
2 \\
0 \\
1 \\
6\end{array}$ & $\mathbf{A}$ & B & C & D \\
\hline \multirow{3}{*}{1.} & \multirow[t]{3}{*}{$\begin{array}{l}\text { PT } \\
\text { Gudang } \\
\text { Garam } \\
\text { Tbk. }\end{array}$} & $\begin{array}{l}2 \\
0 \\
1 \\
3\end{array}$ & 0,294 & 0,405 & 0,195 & 0,437 \\
\hline & & $\begin{array}{l}2 \\
0 \\
1 \\
4 \\
\end{array}$ & 0,261 & 0,452 & 0,2 & 0,448 \\
\hline & & $\begin{array}{l}2 \\
0 \\
1\end{array}$ & 0,3 & 0,486 & 0,237 & 0,443 \\
\hline
\end{tabular}




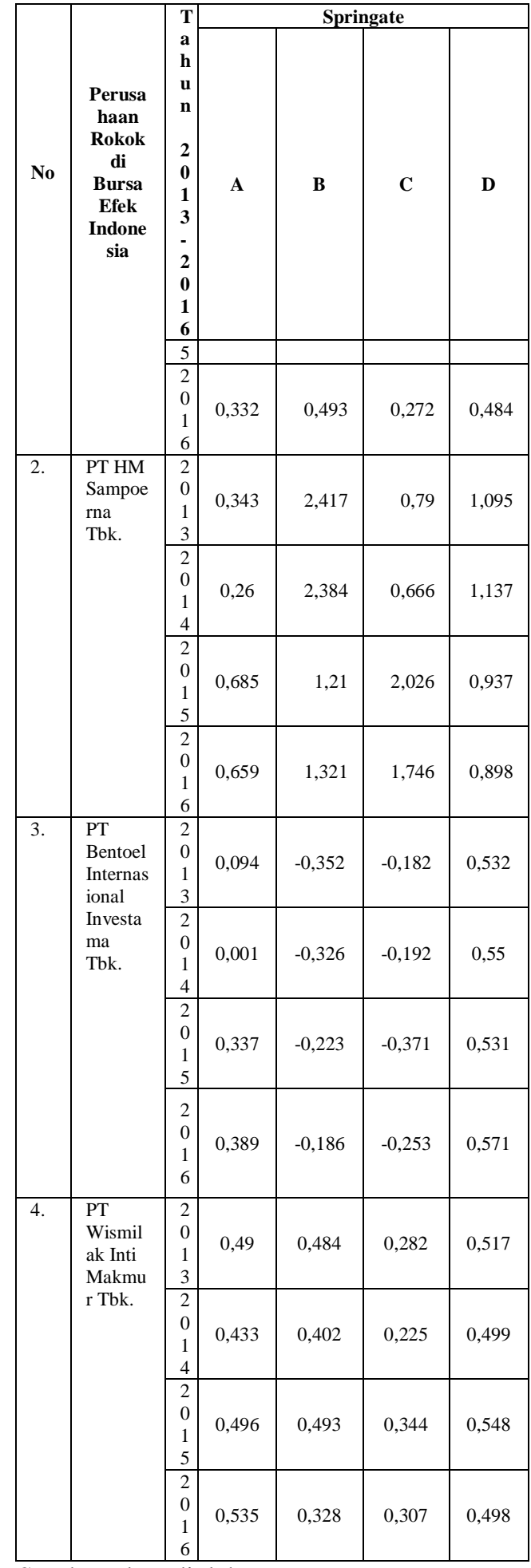

Sumber: data diolah

Tabel 8. Hasil Nilai Springate Tahun 2013-2016

\begin{tabular}{|l|c|c|c|c|}
\hline No. & $\begin{array}{c}\text { Perusahaan } \\
\text { Rokok di } \\
\text { Bursa Efek } \\
\text { Indonesia }\end{array}$ & $\begin{array}{c}\text { Tahun } \\
\mathbf{2 0 1 3 -} \\
\mathbf{2 0 1 6}\end{array}$ & $\begin{array}{c}\text { Total } \\
\text { Hasil } \\
\text { Springate }\end{array}$ & $\begin{array}{c}\text { Ka } \\
\text { teg } \\
\text { ori }\end{array}$ \\
\hline 1. & PT Gudang & 2013 & 1,331 & $S$ \\
\cline { 4 - 5 }
\end{tabular}

\begin{tabular}{|l|l|l|l|l|}
\multirow{2}{*}{} & Garam Tbk. & 2014 & 1,361 & $S$ \\
\cline { 3 - 5 } & & 2015 & 1,467 & $S$ \\
\cline { 3 - 5 } & & 2016 & 1,583 & $S$ \\
\hline 2. & PT HM & 2013 & 4,645 & $S$ \\
\cline { 3 - 5 } & Sampoerna & 2014 & 4,447 & $S$ \\
\cline { 3 - 5 } & Tbk. & 2015 & 4,858 & $S$ \\
\cline { 3 - 5 } & & 2016 & 4,624 & $S$ \\
\hline 3. & PT Bentoel & 2013 & 0,092 & $D$ \\
\cline { 3 - 5 } & Internasional & 2014 & 0,033 & $D$ \\
\cline { 3 - 5 } & Investama & 2015 & 0,274 & $D$ \\
\cline { 3 - 5 } & Tbk. & 2016 & 0,521 & $D$ \\
\hline 4. & PT Wismilak & 2013 & 1,773 & $S$ \\
\cline { 3 - 5 } & Inti Makmur & 2014 & 1,559 & $S$ \\
\cline { 3 - 5 } & Tbk. & 2015 & 1,881 & $S$ \\
\cline { 3 - 5 } & & 2016 & 1,668 & $S$ \\
\hline
\end{tabular}

Sumber: data diolah

Keterangan:

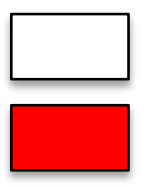

$$
\begin{aligned}
& =\quad \text { Safe Zone (Zona } \\
& \text { Aman) } \\
& =\text { Distress Zone (Zona } \\
& \text { Kesulitan) }
\end{aligned}
$$

Disimpulkan dari keempat perusahaan tersebut hanya ada satu perusahaan yang berada dalam posisi Distress Zone atau mengalami kesulitan keuangan yang berpotensi besar mengalami kebangkrutan. Perusahaan tersebut yaitu PT Bentoel Internasional Investama Tbk., selama 4 (empat) tahun perusahaan ini selalu mengalami kesulitan keuangan, ini dikarenakan selama empat tahun perusahaan tersebut menunjukkan laba yang diperoleh selalu mengalami kerugian. Dimana perusahaan tersebut mempunyai hutang yang cukup besar. Kejadian ini dapat ditunjukkan dari perhitungan pada perusahaan Bentoel Internasional Investama selama empat tahun bernilai negatif. 


\subsection{Metode Zmijewski}

Berdasarkan penelitian pada 4 perusahaan rokok periode 2013-2016 dengan metode Altman menggunakan persamaan $X=-4,3-4,5 X_{1}+5,7 X_{2}+$ $0,004 X_{3}$. Setelah dilakukan perhitungan setiap variabel dengan cut-off $\mathrm{Z}<0$ (negatif) termasuk kategori safe zone, dan $Z>0$ (positif) merupakan kategori distress zone. Maka diperoleh hasil $\mathrm{Z}$ dengan kategori sebagai berikut:

Tabel 9. Hasil Nilai $X_{1}-X_{2}$ Tahun 2013-2016

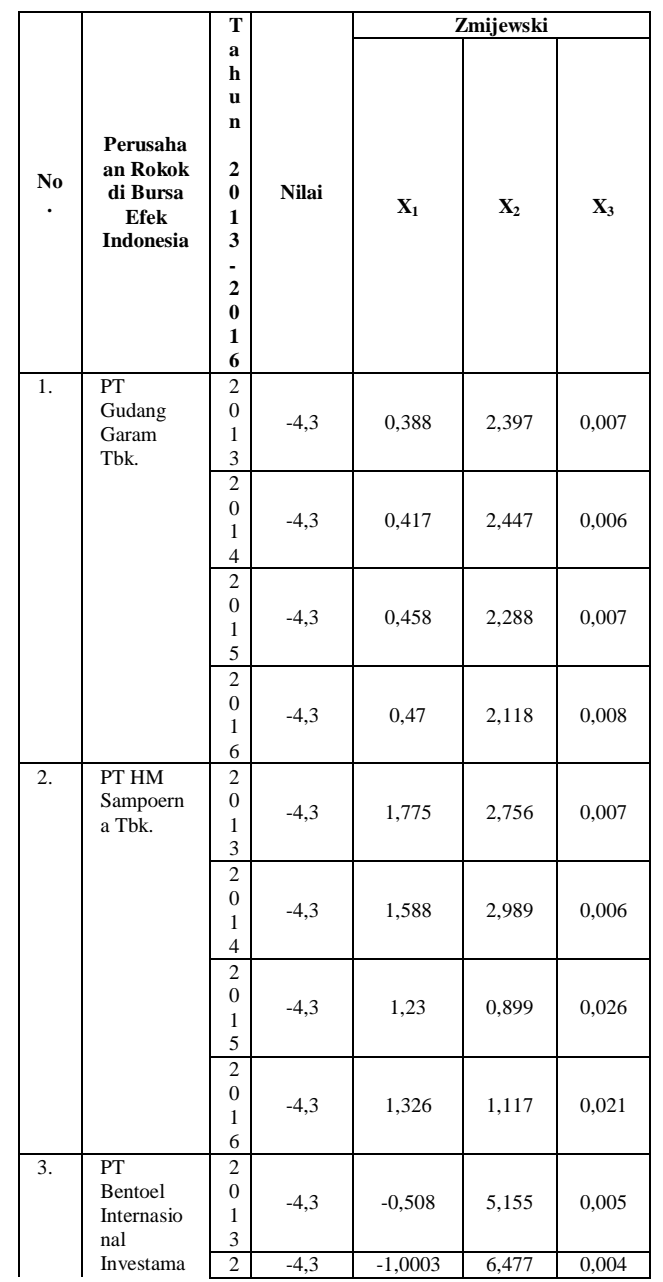

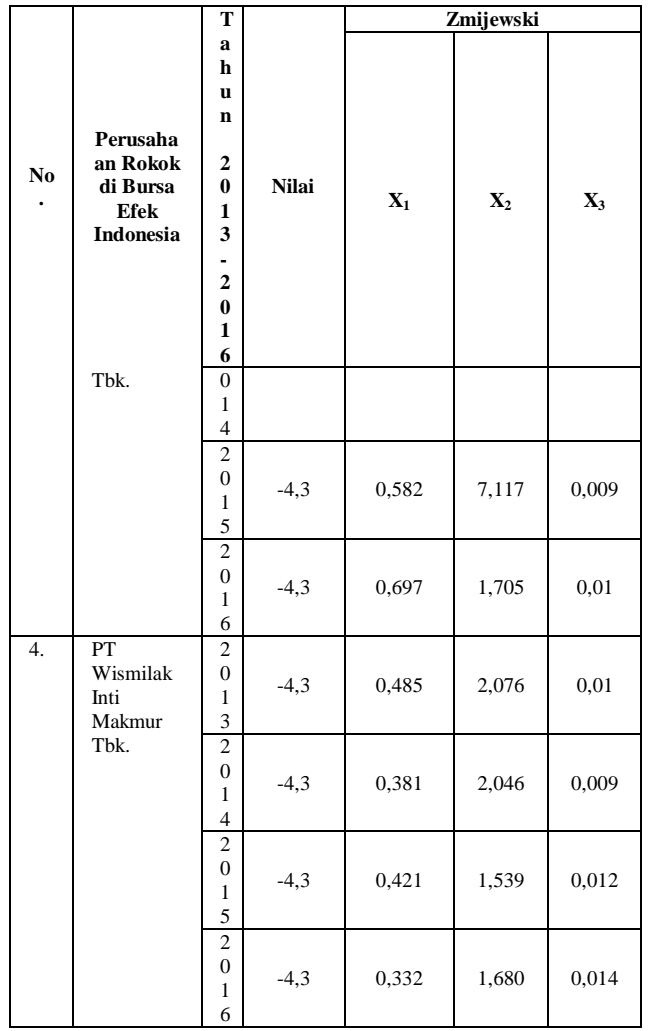

Sumber: data diolah

Tabel 10. Hasil Nilai Zmijewski Tahun 2013-2016

\begin{tabular}{|c|c|c|c|c|}
\hline $\begin{array}{c}\text { No } \\
\cdot\end{array}$ & $\begin{array}{c}\text { Perusahaa } \\
\text { n Rokok di } \\
\text { Bursa Efek } \\
\text { Indonesia } \\
\end{array}$ & $\begin{array}{c}\text { Tahun } \\
\text { 2013- } \\
2016\end{array}$ & $\begin{array}{c}\text { Total } \\
\text { Hasil } \\
\text { Zmijews } \\
\text { ki }\end{array}$ & $\begin{array}{l}\text { Kate } \\
\text { gori }\end{array}$ \\
\hline \multirow[t]{4}{*}{1.} & \multirow[t]{4}{*}{$\begin{array}{l}\text { PT Gudang } \\
\text { Garam Tbk. }\end{array}$} & 2013 & $-2,284$ & $S$ \\
\hline & & 2014 & $-2,264$ & $S$ \\
\hline & & 2015 & $-2,462$ & $S$ \\
\hline & & 2016 & $-2,645$ & $S$ \\
\hline \multirow[t]{4}{*}{2.} & \multirow{4}{*}{$\begin{array}{l}\text { PT HM } \\
\text { Sampoerna } \\
\text { Tbk. }\end{array}$} & 2013 & $-3,312$ & $S$ \\
\hline & & 2014 & $-2,893$ & $S$ \\
\hline & & 2015 & $-4,601$ & $S$ \\
\hline & & 2016 & $-4,488$ & $S$ \\
\hline \multirow[t]{4}{*}{3.} & \multirow{4}{*}{$\begin{array}{l}\text { PT Bentoel } \\
\text { Internasion } \\
\text { al } \\
\text { Investama } \\
\text { Tbk. }\end{array}$} & 2013 & 1,368 & $D$ \\
\hline & & 2014 & 3,181 & $D$ \\
\hline & & 2015 & 2,244 & $D$ \\
\hline & & 2016 & $-3,282$ & $S$ \\
\hline \multirow[t]{4}{*}{4.} & \multirow{4}{*}{$\begin{array}{l}\text { PT } \\
\text { Wismilak } \\
\text { Inti } \\
\text { Makmur } \\
\text { Tbk. }\end{array}$} & 2013 & $-2,699$ & $S$ \\
\hline & & 2014 & $-2,626$ & $S$ \\
\hline & & 2015 & $-3,17$ & $S$ \\
\hline & & 2016 & $-2,938$ & $S$ \\
\hline
\end{tabular}


Sumber: data diolah

Keterangan:

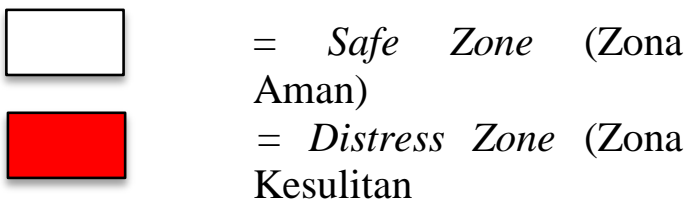

Disimpulkan bahwa dari keempat perusahaan tersebut hanya ada satu yang berada pada posisi Distress Zone, yaitu perusahaan Bentoel Internasional Investama Tbk.. Perusahaan tersebut mengalami kesulitan keuangan pada tahun 2013-2015 yaitu selama kurun waktu tiga tahun. Hal ini dapat ditunjukkan dari hasil perhitungan nilai rasio yang menunjukkan bahwa selama tiga tahun perusahaan tersebut mempunyai hutang yang cukup besar dibandingkan dengan aktiva perusahaan. Namun, pada tahun 2016 perusahaan tersebut mampu berada dalam kondisi Safe Zone. Hal ini menunjukkan bahwa perusahaan tersebut mampu memperbaiki kondisi keuangan perusahaan.

\subsection{Perbedaan Hasil Prediksi Financial Distress Tahun 2013- 2016}

Setelah melakukan perhitungan dan memperoleh nilai Z' pada setiap metode prediksi kebangkrutan maka langkah selanjutnya adalah melakukan perbandingan hasil dari setiap metode yang digunakan dengan tujuan untuk mengetahui perbedaan dan kemampuan setiap metode dalam memprediksi kebangkrutan pada empat perusahaan rokok pada periode 2013-2016. Analisis prediksi kebangkrutan dari perusahaan rokok batubara yang terdaftar di BEI dengan menggunakan tiga metode prediksi kebangkrutan yaitu metode Altman Z-Score, Metode Springate dan Metode Zmijewski, diperoleh hasil yang dapat dilihat pada Tabel 11 .

Tabel 11. Data Hasil Perbandingan Kebangkrutan Dengan Metode Altman Z-Score, Springate dan Zmijewski Perusahaan Rokok Tahun 2013-2016.

\begin{tabular}{|l|c|c|c|}
\hline \multirow{2}{*}{ Kategori } & \multicolumn{3}{|c|}{ Persentase Perbandingan Tiga Metode } \\
\cline { 2 - 4 } & $\begin{array}{c}\text { Altman Z- } \\
\text { Score }\end{array}$ & Springate & Zmijewski \\
\hline $\begin{array}{l}\text { Safe } \\
\text { Zone }\end{array}$ & $50,00 \%$ & $75,00 \%$ & $81,25 \%$ \\
\hline $\begin{array}{l}\text { Grey } \\
\text { Zone }\end{array}$ & $25,00 \%$ & - & - \\
\hline $\begin{array}{l}\text { Distress } \\
\text { Zone }\end{array}$ & $25,00 \%$ & $25,00 \%$ & $18,75 \%$ \\
\hline
\end{tabular}

Sumber: data diolah

Dari perbandingan Score ketiga metode selama 2013-2016 diatas dapat dilihat bahwa metode Altman Z-Score dan Springate memberikan tingkat prediksi kebangkrutan yang sama 
dengan nilai presentase sebesar 25,00 persen. Namun berbeda dengan penggunaan metode Zmijewski yang memberikan presentase nilai kebangkrutan sebesar 18,75 persen.

Perhitungan secara keseluruhan dapat disimpulkan bahwa, jika melihat dari sisi prediksi kebangkrutan perusahaan rokok yang masuk dalam kategori bangkrut, maka metode Altman Z-Score dan metode Springate yang memberikan penilaian prediksi kebangkrutan yang cukup rendah apabila dibandingkan dengan metode Zmijewski.

Perbandingan ketiga metode Altman Z-Score, metode Springate dan metode Zmijewski memberikan gambaran perusahaan rokok termasuk dalam kategori perusahaan yang mengalami Safe Zone. Namun ada pula perusahaan yang berada di posisi Distress Zone, jika hal ini terus berlanjut maka tidak menutup kemungkinan perusahaan tersebut benar-benar bangkrut. Hal inilah yang seharusnya menjadi perhatian semua pemangku kepentingan baik dari manajemen perusahaan maupun investor untuk mencari solusi yang baik guna meningkatkan kinerja perusahaan. Maka dari itu metode prediksi yang cocok untuk perusahaan rokok di Indonesia adalah metode Zmijewski guna menarik investor yang akan menanamkan sahamya di perusahaan rokok karena dapat dilihat bahwa tingkat presentase perusahaan yang berada di posisi safe zone sangat tinggi dan posisi distress zone sangat rendah dibanding dua metode lainnya.

\section{PENUTUP}

\subsection{Simpulan}

Penelitian ini bertujuan untuk mengetahui perbandingan prediksi kebangkrutan dengan menggunakan metode Altman Z-Score, metode Springate dan metode Zmijewski, berikut kesimpulan dari hasil penelitian:

1. Metode Altman Z-Score dan metode Springate merupakan metode prediksi kebangkrutan yang memberikan nilai sama yang cukup rendah dalam memprediksi kebangkrutan pada perusahaan rokok dengan nilai prediksi kebangkrutan sebesar 25,00 persen.

2. Metode Zmijewski merupakan metode prediksi kebangkrutan yang memberikan nilai yang juga cukup rendah dibandingkan kedua metode lainnya dalam 
memprediksi kebangkrutan pada perusahaan rokok dengan nilai prediksi kebangkrutan sebesar 18,75 persen.

\subsection{Saran}

Berdasarkan hasil penelitian yang telah dilakukan pada empat perusahaan rokok yang terdaftar di Bursa Efek Indonesia (BEI) periode 2013-2016, maka peneliti memberikan saran sebagai berikut:

1. Bagi perusahaan yang terprediksi sebagai perusahaan bangkrut, maka pihak manajemen perusahaan harus segera mencari solusi yang tepat guna meningkatkan kinerja perusahaan.

2. Bagi investor ini merupakan early warning dalam melakukan keputusan investasi sehingga harus lebih selektif dalam memilih perusahaan terutama perusahaan-perusahaan yang memiliki kinerja keuangan yang baik, sehingga investor dapat menginvestasikan dananya dengan lebih aman.

\section{DAFTAR PUSTAKA}

Kamal, ST Ibrah Mustafa.2012.Analisis Prediksi Kebangkrutan Pada Perusahaan Perbankan Go Public
Di Bursa Efek Indonesia (dengan menggunakan Model Altman ZScore).Makassar: Program Studi Jurusan Manajemen Fakultas Ekonomi Dan Bisnis Universitas Hasanuddin.
Nurcahyanti,
Wahyu.2015.Studi Komparatif Model Z-Score Altman, Springate dan Zmijewski Dalam Mengindikasikan Kebangkrutan Perusahaan Yang Terdaftar di Bursa Efek Indonesia (online) https://www.google.co.id/?gws_rd $=\mathrm{cr}, \mathrm{ss} / \& \mathrm{ei}=\mathrm{qNuNVuGEGs6Duw}$ TQ3YHgBg\# (diakses pada 10 April 2018)

Peter dan Yoseph.2011.Analisis Kebangkrutan Dengan Metode ZScore Altman, Springate dan Zmijewski Pada PT. Indofood Sukses Makmur Tbk Periode 2005-2009.Jurusan Manajemen, Universitas Kristen Maranatha. Akurat Jurnal Ilmiah Akuntansi Nomor 04.

www.bentoelgroup.com

www.gudanggaramtbk.com

www.idx.co.id

www.sampoerna.com

www.wismilak.com 